\title{
The role of video game playing in adolescent life: Is there reason to be concerned?
}

\author{
ERIC A. EGLI and LAWRENCE S. MEYERS \\ California State University, Sacramento, California
}

\begin{abstract}
One hundred fifty-one subjects from 10 to 20 years old were surveyed to determine their attitudes toward video game playing and its role in their lives. Concerns have been expressed in the public media that video game playing is addictive for youngsters and leads to excessive expenditures of time and money, poorer school performance, reduced involvement in sports, and less opportunity to develop social skills. The survey data did not support these contentions. Although approximately $10 \%$ of the subjects appeared to show some compulsive aspects in their play, no identifiable problems were correlated with the amount of time spent playing. For the great majority, video game playing was an enjoyable activity held in perspective with other aspects of their lives.
\end{abstract}

One result of the recent progress in microcomputer technology has been the development of video game machines. Although introduced in a primitive form in 1972, their greatest rise in sophistication and popularity began in 1979 with the introduction of the game Space Invaders (Surrey, 1982). In the period from 1979 to late 1981 , game sales rose from approximately $\$ 40$ million to about $\$ 500$ million (Greenburg, 1981b). By 1982 , approximately $\$ 4$ billion worth of quarters was being spent to play games annually across the world (Surrey, 1982).

The rapid growth in video game popularity, together with the avid way young people play, has generated concern among social scientists, parents, and politicians about the effect the games have on their players (e.g., Greenburg, 1981a; Mandel, 1983). Such concerns include the fears that young people who play video games will not develop necessary social skills due to the apparent nonsocial nature of such playing and that video game playing is an addictive type of behavior, resulting in players' spending excessive amounts of money on the games, participating less in active sports, and ignoring school work. Further concerns are that the violent themes common in video games may encourage generalized aggressive behavior and that the social milieu of video game arcades encourages drug abuse, loitering, and other problems.

The first attempts to address these issues were reported by Brooks (1983), who conducted a large survey of video game players in arcades in Los Angeles, California, and by Mitchell (1983), who studied the impact of home video games on family life. Brooks (1983) reported that

We gratefully acknowledge the arcade owners' cooperation in allowing us to conduct the survey on their premises. Requests for reprints should be sent to Eric A. Egli, who is now at the Department of Psychology, University of Minnesota, Minneapolis, MN 55455.
$68 \%$ or more of those surveyed had at least a $\mathrm{C}$ average in school, more than half had full or part-time jobs, and $39 \%$ participated in extracurricular activities at school. In addition, the majority of the youths in the arcades played less than half the time they were inside, spending the rest of the time talking to friends or watching others playing the games. His conclusion was that video game playing was to some degree a social activity, and not as "compulsive" as it might appear at first glance. Mitchell (1983) reported that families generally felt that having video games at home promoted family interaction in a beneficial way through cooperation and competition. Although these studies provided a good set of preliminary data, they made no assessment of the attitudes and personal characteristics of players in the arcades and did not investigate relationships between amount of time devoted to playing and other aspects of the players' lives.

This paper reports the results of a survey designed to gather information about who is playing video games, the role of video game playing in their lives, and whether playing video games has any perceived positive or negative impact on their lives. Because concerns about the impact of video game playing are expressed primarily with regard to adolescents, only individuals from the ages of 10 to 20 years were included in the survey.

\section{METHOD}

\section{Subjects}

The subjects were 151 males and females interviewed in three video game arcades in Sacramento, California, and one arcade in Davis, California. Of 181 individuals asked to participate, 28 refused, resulting in 153 completed surveys. Of these, 2 were for individuals over 20 years old and were excluded from the analysis, leaving a total of 151 subjects. Women were a minority in the arcades, reflected by the fact that only 10 of the subjects who completed the survey were female. Although their data are included in subsequent analyses, the variable of sex itself is not treated. 


\section{Survey Construction}

Survey questions were constructed on the basis of concerns expressed regarding the effects of video game playing on the participants. In addition to determining general attitudes toward the playing of video games, questions addressed the issues of drug use, how important a role video game playing had in their lives, how much time and money were spent, and whether and in what way participants felt playing video games was a source of problems in their lives.

Two trial versions of the survey were created and tested on small samples to ensure clarity and appropriateness of wording. The final version began with 10 questions on demographics and frequency of playing, followed by 4 questions on attitudes toward video game playing. Answers were made on a 7-point scale with verbal anchors of "agree" at 1 , "neutral" at 4 , and "disagree" at 7. These were followed by 24 statements on which the subjects rated themselves in response to the question "To what extent do the following statements apply to you?"; the subjects used a 7-point scale with verbal anchors of "very little" at 1 and "very much" at 7 .

\section{Survey Administration}

The survey was administered in the spring and summer of 1983. The subjects were approached while they were walking in the arcade looking for the next game to play, but not while they were playing or watching another person play a game. They were given a card showing the appropriate scale, and the experimenter read the questions and recorded the responses.

\section{RESULTS}

\section{Demographics}

The subjects had been playing video games for an average of 4.3 years $(\mathrm{SD}=2.0)$, with a frequency ranging from almost never to 7 days per week (mean $=2.5$ ). They played from $15 \mathrm{~min}$ to $5 \mathrm{~h}$ each time they went to the arcade (mean $=1.8 \mathrm{~h}$ ). The product of frequency and duration of arcade visits was used to give the number of hours played per week for each subject. The resulting distribution of number of hours played per week was strongly skewed, with values ranging from 0 to 35 (mean $=5.2$, median $=2.5$ ). The amount of money spent per week ranged from $\$ 0$ to $\$ 70.00$ (mean $=\$ 7.80$, median $=\$ 5.00)$. Sixty-six percent of those interviewed had a video game player at home, but indicated they preferred playing in arcades because of the greater variety and quality of games available. In spite of the fact that many had been playing the games for several years, $52 \%$ indicated they were playing more than they had been 1 year ago, $18 \%$ said they were playing the same, and $30 \%$ said they were playing less.

\section{The Role of Video Game Playing in Subjects' Lives}

An examination of the correlation matrix for the 28 scaled variables and the amount of time spent playing per week showed numerous correlations exceeding .30 , indicating that an exploratory factor analysis of the data was warranted. The data were analyzed via the principal components method, followed by a varimax rotation. The optimum solution included two factors based upon interpretability and the scree test for roots (Cattell, 1966). Together, these factors accounted for $32 \%$ of the variance in the survey. The text, mean, and factor loading for questions loading on each factor are included in Tables 1 and 2. With a loading of .45 as the cutoff, 12 variables did not load strongly enough to be included in one of the two factors, and these are discussed separately.

Factor 1 included questions relating to the importance or "compulsiveness" of video game playing in the subjects' lives. Questions loading on this factor are shown in Table 1. These questions reflect whether the subjects feel addicted to playing video games, how much they play, how hard a time they have stopping, whether it causes problems in their lives, and whether there is anything else they enjoy doing as much. Although these questions appear to reflect undesirable qualities, their mean values are quite low, indicating that they are not seen as serious problems by most subjects.

Although not included in Factor 1, the statement "I usually spend more time and money than I had planned to once I get to an arcade" correlated with how addicted the subjects felt $[\mathrm{r}(149)=.37, \mathrm{p}<.05$, mean $=$ 4.5]. No correlation was found between feeling addicted or amount of playing and extent of participation in active sports or how good a student the subject reported he or she was.

Although our demographic data show that most individuals do not spend large amounts of time playing video games, some individuals clearly do. To evaluate whether responses by high-frequency players differed from those by lower frequency players, the data were dichotomized into those playing 12 or more hours per week $(\mathrm{N}=20)$ and those playing less $(\mathrm{N}=131)$. A 12-h cutoff was slected because of the time commitment it represented and because a break occurred around this point between the low-to-moderate-frequency and the high-frequency players. A multivariate analysis of variance demonstrated that the responses of the two groups

Table 1

Factor Loadings (FL), Text, and Mean Values for Questions Loading on Factor 1

\begin{tabular}{|c|c|c|c|c|}
\hline Item & Question & Mean & SD & FL \\
\hline 12 & $\begin{array}{l}\text { There is nothing I enjoy as much } \\
\text { as playing video games. }\end{array}$ & 2.8 & 1.8 & .54 \\
\hline 13 & $\begin{array}{l}\text { I get bored easily when I'm not } \\
\text { playing video games. }\end{array}$ & 3.1 & 2.0 & .45 \\
\hline 14 & $\begin{array}{l}\text { The extent to which I play video } \\
\text { games causes problems in my life. }\end{array}$ & 1.9 & 1.2 & .46 \\
\hline 16 & $\begin{array}{l}\text { I feel like I'm addicted to } \\
\text { playing video games. }\end{array}$ & 3.0 & 2.1 & .66 \\
\hline 22 & $\begin{array}{l}\text { Once I get started playing, I } \\
\text { have a hard time stopping. }\end{array}$ & 3.9 & 2.1 & .45 \\
\hline 23 & $\begin{array}{l}\text { I get bothered if I don't play } \\
\text { video games every day or two. }\end{array}$ & 2.2 & 1.6 & .68 \\
\hline \multirow[t]{2}{*}{27} & $\begin{array}{l}\text { I spend most of my spare time } \\
\text { playing video games. }\end{array}$ & 2.9 & 1.8 & .71 \\
\hline & Hours per week played. & 5.1 & 6.6 & .71 \\
\hline
\end{tabular}

Note-All items were scaled from $1=$ "very little" to $7=$ "very much." 
on the 24 self-rating questions were significantly different [Wilks' $\lambda(30,120)=.69, p<.05$ ]. A series of univariate $F$ tests with 1,149 degrees of freedom at $\alpha=.01$ revealed that four questions were answered differently by the two groups (all questions were scaled from $1=$ "very little" to 7 = "very much"). Frequent players were more concerned with how they played compared with how others played than were less frequent players (means = 4.8 and 2.4 , respectively, $F=8.2$ ). Frequent players were also more bothered than less frequent players if they did not play every day or two (means $=3.5$ and 2.5 , respectively, $F=17.0$ ) and indicated more strongly that they spent most of their spare time playing video games (means $=4.2$ and 2.3, respectively, $\mathrm{F}=17.2$ ). The greatest difference was that frequent players indicated more strongly that they felt addicted to playing video games than did less frequent players (means = 5.1 and 2.3, respectively, $F=24.6$ ).

Questions loading on Factor 2 are shown in Table 2. These reflect how video game playing makes the subjects feel and the use of video games as an outlet for calming down, forgetting problems, and increasing self-esteem. Also, the effect of video games on making subjects interested in how computers work loaded positively, perhaps reflecting the use of video games as an intellectual outlet. Social aspects were reflected by positive loadings on enjoyment from watching others play and overall shyness.

Several questions that did not load on these factors are of interest. Looking first at issues scaled along the agree-disagree dimension, the subjects were widely divided on whether video games were a passing fad, although they tended to disagree (mean $=4.8, \mathrm{SD}=$ 2.0). They were also divided about whether video games

Table 2

Factor Loadings (FL), Text, and Mean Values for Questions Loading on Factor 2

\begin{tabular}{rlrcc}
\hline Item & \multicolumn{1}{c}{ Question } & Mean & SD & FL \\
\hline 7 & $\begin{array}{l}\text { I think about playing video games } \\
\text { when I am away from them. }\end{array}$ & 3.3 & 1.9 & .47 \\
9 & $\begin{array}{l}\text { How well I play video games helps } \\
\text { me feel good about myself. }\end{array}$ & 4.2 & 1.8 & .48 \\
17 & 3.3 & 2.0 & .52 \\
18 & $\begin{array}{l}\text { I tend to be shy. } \\
\text { I enjoy watching my friends and } \\
\text { others play. }\end{array}$ & 5.2 & 1.7 & .49 \\
19 & 4.0 & 2.0 & .73 \\
$\begin{array}{l}\text { Playing video games helps me } \\
\text { forget my problems. } \\
24\end{array}$ & $\begin{array}{l}\text { Playing video games has made me } \\
\text { interested in learning about how } \\
\text { computers work. }\end{array}$ & 5.1 & 1.9 & .51 \\
26 & $\begin{array}{l}\text { Playing video games is one of } \\
\text { the things I do best. }\end{array}$ & 3.7 & 1.9 & .62 \\
28 & $\begin{array}{l}\text { Playing video games calms me } \\
\text { down if I'm upset. }\end{array}$ & 3.8 & 1.9. & .68 \\
30 & $\begin{array}{l}\text { I would watch much more television } \\
\text { if I didn't play video games. }\end{array}$ & 3.8 & 2.2 & .48 \\
\hline
\end{tabular}

Note-All items were scaled from $1=$ "very little" to $7=$ "very much." cost too much (mean $=3.7, \mathrm{SD}=1.9$ ). This response is not too surprising in that youngsters from a wide variety of backgrounds appeared to be represented in the arcades. The subjects disagreed quite strongly that video games promoted the use of drugs (mean $=5.6, \mathrm{SD}=$ 1.7 ) and agreed that they felt safe in arcades (mean $=$ 3.1, $\mathrm{SD}=1.7$ ).

On issues scaled from $1=$ "very little" to $7=$ "very much," subjects reported little interference with family life (mean $=1.9, \mathrm{SD}=1.4$ ), responded strongly that the companionship of their friends was very important to them (mean $=5.9, \mathrm{SD}=1.4)$, and indicated that they participated regularly in sports requiring physical activity (mean $=5.5, \mathrm{SD}=1.8)$. They generally felt that all their friends enjoyed playing video games (mean $=5.7, \mathrm{SD}=$ 1.4), were not particularly concerned with how they played compared with others (mean $=3.5, \mathrm{SD}=2.1$ ), and considered themselves slightly above average in school (mean $=5.1, \mathrm{SD}=1.4$ ). They were evenly divided about whether they took out their frustrations on video games $($ mean $=4.0, \mathrm{SD}=2.1$ ).

\section{DISCUSSION}

Little support was found for the notion that playing video games reduces participation in active sports or that it is related to poor school performance. With few exceptions, playing video games was a minor part of the subjects' lives, held in perspective with other activities. High overall means on the importance of friendships, enjoyment of watching others play, and the fact that all their friends enjoy playing support the view that visiting arcades is in fact a social activity. Some support was found for the idea that playing video games can encourage interest in learning about how computers function. Although counts were not taken, it was clear that most of those in arcades had come with friends and interacted with them during their visit. Regarding school performance, the subjects rated themselves somewhat above average. They may either have tended to rank themselves too highly or indeed have been better than average students. These results were consistent with those of Brooks (1983), who found that most video game players he interviewed had a better than $\mathrm{C}$ average in school.

For some, video game playing did show elements of being a compulsive behavior. These people played the most and indicated they felt somewhat addicted to playing video games, tended to enjoy video game playing more than almost anything else, and were more inclined to be competitive. When asked, several of those who answered strongly that they felt addicted explained their responses by saying they felt a strong impulse to play the games whenever they were around them, that is, that the games were difficult for them to resist. This group represented at most $10 \%-15 \%$ of the sampled population; they were those who played $12 \mathrm{~h}$ or more a week and who scored relatively highly on questions in the factor relating to compulsiveness. Whether this represents a true personal or social problem is hard to ascertain, however, because the amount of time spent playing was weakly or not at all correlated with questions addressing popular concerns about video games or self-report of other problems in their lives. In addition, mean values for items reflecting popular concerns were so low that they did not appear to represent problems for the youngsters. This may reflect denial commonly observed with addictive behaviors, but no evidence is available to support that contention. The 5\%-6\% who played over $20 \mathrm{~h}$ per week may have been playing excessively, but perhaps not relative to what else they would be doing. Of the 20 subjects who played 12 or more hours per week, 
3 stated that they would probably be out in the streets getting into trouble if they were not playing video games. A few said they would play more sports, and others had no idea what else they might do.

Although the results of this study reflect a predominately white, middle-class group of subjects, the arcades sampled included the most popular ones in the Sacramento area. If the problems with video game playing were as great as the concerns expressed in the popular media, evidence should have been found to support them. The possibility exists that among other socioeconomic groups such problems would be greater, but this seems unlikely in light of the expenses involved in regular play and arcade rules that strictly forbid loitering, drugs, and fighting. In the absence of more definitive studies, the expressions of concern regarding the effect of video games on today's youth seem premature.

\section{REFERENCES}

Brooks, B. D. (1983). [Untitled]. In S. S. Baughman \& P. D. Clagett (Eds.), Video Games and Human Development: A Research Agenda for the '80's. Papers and proceedings of the symposium held at the Harvard Graduate School of Education. Cambridge, MA: Gutman Library, Harvard Graduate School of Education.

Cattell, R. B. (1966). The scree test for the number of factors. Multivariate Behavioral Research, 1, 245-276.

Greenburg, J. (1981a, April). Games addicts play. Forbes, p. 102. GREENBURG, J. (1981b, April). Japanese invaders. Forbes, pp. 98, 102. MANDEL, H. (1983, February). Dr. Video: NCTV takes stand on video game violence. Video Games, pp. 97-98.

Mitchell, E. (1983). [Untitled]. In S. S. Baughman \& P. D. Clagett (Eds.), Video Games and Human Development: A Research Agenda for the '80's. Papers and proceedings of the symposium held at the Harvard Graduate School of Education. Cambridge, MA: Gutman Library, Harvard Graduate School of Education.

Surrey, D. (1982, November). "It's, like, good training for life." Natural History, pp. 70-72, 74, 76-78, 80, 82-83.

(Manuscript received for publication March 22, 1984.) 